OPEN ACCESS

Edited by:

Hiroaki Itoh,

Hamamatsu University School of Medicine, Japan

Reviewed by:

Noriko Sato,

Tokyo Medical and Dental University,

Japan

Takahiro Nemoto,

Nippon Medical School, Japan

*Correspondence:

Satoru Ikenoue

sikenoue.a3@keio.jp

Specialty section:

This article was submitted to Pediatric Endocrinology,

a section of the journal

Frontiers in Endocrinology

Received: 12 May 2021

Accepted: 28 June 2021

Published: 22 July 2021

Citation:

Ikenoue S, Kasuga Y, Endo T. Tanaka M and Ochiai D (2021)

Newer Insights Into Fetal Growth and Body Composition.

Front. Endocrinol. 12:708767. doi: 10.3389/fendo.2021.708767

\section{Newer Insights Into Fetal Growth and Body Composition}

\author{
Satoru Ikenoue*, Yoshifumi Kasuga, Toyohide Endo, Mamoru Tanaka and Daigo Ochiai \\ Department of Obstetrics and Gynecology, Keio University School of Medicine, Tokyo, Japan
}

Based on epidemiological and experimental evidence, the origins of childhood obesity and early onset metabolic syndrome can be extended back to developmental processes during intrauterine life. It is necessary to actively investigate antecedent conditions that affect fetal growth by developing reliable measures to identify variations in fetal fat deposition and body composition. Recently, the resolution of ultrasonography has remarkably improved, which enables better tissue characterization and quantification of fetal fat accumulation. In addition, fetal fractional limb volume has been introduced as a novel measure to quantify fetal soft tissue volume, including fat mass and lean mass. Detecting extreme variations in fetal fat deposition may provide further insights into the origins of altered fetal body composition in pathophysiological conditions (i.e., fetal growth restriction or fetal macrosomia), which are predisposed to the metabolic syndrome in later life. Further studies are warranted to determine the maternal or placental factors that affect fetal fat deposition and body composition. Elucidating these factors may help develop clinical interventions for altered fetal growth and body composition, which could potentially lead to primary prevention of the future risk of metabolic dysfunction.

Keywords: DOHaD, fetal ultrasound, fetal body composition, fetal subcutaneous fat, fractional limb volume, fetal growth restriction, macrosomia, predisposition

\section{INTRODUCTION}

Fetal growth is an important predictor of perinatal outcomes. Previous studies have also shown that birth weight is associated with future risk of obesity and metabolic dysfunction in the offspring. Barker et al. reported that low birthweight infants are predisposed to cardiovascular disease in adulthood (1). Maternal undernutrition during pregnancy leads to increased risks of cardiovascular disease in the offspring in later life (2). Meanwhile, the infants of mothers with gestational diabetes have increased adiposity (3). Large-for-gestational age (LGA) neonates born to mothers with gestational diabetes are predisposed to early onset metabolic syndrome (4).

These experimental and epidemiological evidence have shown that the origins of early onset metabolic syndrome can be extended back to developmental processes during intrauterine life (Developmental Origins of Health and Disease) (5-7). Therefore, it is necessary to actively investigate the antecedent conditions that affect fetal growth by developing reliable measures to identify variations in fetal growth and body composition. 


\section{BODY WEIGHT AND BODY COMPOSITION}

Total body weight and height has been traditionally used as the gold standard for the measurement of body size and nutritional status. Recently, the concept of body composition has been introduced, which is composed of fat mass, lean mass, and bone mineral content.

\section{Neonatal Body Composition}

Previous studies on infant body size have mainly relied on heightand weight-based measures (i.e. weight for length, body mass index, or ponderal index). However, these parameters are indirect measures of fat mass or lean mass, and only moderately correlate with percent body fat (8). Newborns with decreased percentage body fat are reported to be at risk of hypoglycemia and short-term morbidity (9). Small-for-gestational age (SGA) newborns, who are supposed to be predisposed to thrifty phenotype, have lower body fat percentage compared to appropriate-for-gestational age infants (10). Higher neonatal body fat percentage is also associated with increased adiposity in childhood (11). These reports suggest that neonatal body composition and body fat percentage could be a more specific marker of future risk of metabolic syndrome as compared with birth weight $(11,12)$.

The body fat percentage of neonates is higher in humans than in other mammals. It is important for human neonates to prioritize adipose tissue accumulation because adipose tissue is an important buffer against limited nutrient supply soon after birth, and could be utilized as one of the brain's energy resources (13). Indeed, the infant brain requires approximately half of the total energy needs, and ketone bodies derived from adipose tissue can provide a quarter of this requirement (14). Consequently, although neonatal fat mass constitutes only $14 \%$ of birth weight, it accounts for a larger variation $(46 \%)$ in birth weight $(15,16)$. In contrast, the ponderal index explains only $22 \%$ of the variation in birth weight and correlates poorly with body fat percentage (16).

Dual-energy X-ray absorptiometry and air displacement plethysmography have recently been used as gold standards for measuring body composition and body fat percentage in infants (17).

\section{Ultrasound-Based Measures of Fetal Weight}

Fetal ultrasonography is commonly used to evaluate fetal growth in clinical practice, and most studies use conventional biometry (estimated fetal weight). Estimated fetal weight has been reported to be a useful predictor of fetal macrosomia (18), or fetal growth restriction with decreased percent body fat (19). However, the estimated fetal weight can fluctuate by approximately $15 \%$ compared to the actual weight and has poor accuracy, especially for fetuses with growth restriction or macrosomic infants (20). A possible explanation is that the estimated fetal weight is an indirect measure of fat mass or lean mass, and has only a modest association with newborn adiposity (21). However, few studies have incorporated fetal fat mass or lean mass measures into formulas that estimate fetal weight. There have recently been remarkable improvements in the resolution of fetal ultrasonography, which enables better tissue characterization and quantification of fetal fat mass and lean mass. Several studies have been conducted to assess fetal body composition (22) and its correlation with newborn adiposity (Table 1).

\section{Ultrasound-Based Measures of Fetal Body Composition}

Histologically, fetal fat is observed in early gestation (29). However, measures of fetal fat mass or lean mass by ultrasonography are mostly obtained after 20 weeks of gestation because enlargement and accumulation of adipocytes accelerate in the second half of pregnancy (30). Since $70-90 \%$ of total body fat in human infants is subcutaneous and not visceral (31), subcutaneous fat mass is measured for evaluating fetal adiposity. Fetal fat mass can be reliably and reproducibly measured using ultrasonography at the mid-upper arm, mid-thigh, and abdomen (32).

Fetal Fat Mass Measures in the Upper-Arm and Thigh In 1985, Jeanty et al. reported the measurement of subcutaneous fat thickness in the arm and thigh (33). This method yields substantial measurement error because the subcutaneous fat thickness in the limb is not continuous around the limb. In 1997, Bernstein et al. measured the fat area on the arm and thigh, instead of the fat thickness at term gestation. The fat area on the arm and thigh were quantified by subtracting the lean mass area from the total cross-sectional area at the midpoint of the humerus or femur. They reported a significant correlation between the fat area of the limb and newborn fat mass (28).

\section{Fetal Fat Mass Measures in the Abdomen}

In previous studies, abdominal subcutaneous fat thickness was measured as the hyperechoic region anterior to the margins of the ribs. The widest point was selected in the anterior third of the abdominal circumference (34). In 1997, Petrikovsky et al. reported that anterior abdominal wall thickness is useful for ruling out fetal macrosomia (35). Subsequently, in 1999, Gardeil et al. measured anterior abdominal wall thickness as a predictor of fetal growth restriction (34). An increasing amount of evidence has been gathered over the last 20 years in the assessment of fetal body composition and fat mass (22).

\section{Fetal Fat Mass Measures in Other Parts}

In addition to the three major sites (upper-arm, thigh and abdomen), fetal fat is deposited in other areas such as the cheek, ribs, and buttocks $(22,36,37)$. Abramowicz et al. has reported that fetal cheek-to-cheek diameter is useful in the prediction of birth weight and mode of delivery $(36,38,39)$. Matsumoto et al. reported the fetal nutrition score, derived from fetal subcutaneous tissue present at face, ribs and buttocks. The fetal nutrition score significantly correlated with neonatal nutrition score derived from face, ribs, thigh and buttocks (37). However, the accuracy of quantitative measurement of fat mass in these areas has not been validated.

\section{Fetal Fractional Limb Volume}

$3 \mathrm{D}$ ultrasonography refers specifically to the volume rendering of ultrasound data, and is now widely used in the clinical practice including prenatal diagnosis. Fetal fractional limb volume measured by three-dimensional ultrasonography was 
TABLE 1 | Fetal fat mass measures predicting newborn adiposity.

\begin{tabular}{|c|c|c|c|c|c|c|c|c|}
\hline \multirow{2}{*}{$\begin{array}{l}\text { Author, } \\
\text { publication } \\
\text { year }\end{array}$} & \multirow[t]{2}{*}{$\mathbf{N}$} & \multicolumn{2}{|c|}{$\begin{array}{l}\text { Newborn adiposity } \\
\text { measures }\end{array}$} & \multirow[t]{2}{*}{$\begin{array}{c}\text { Gestational age at fetal } \\
\text { ultrasonography }\end{array}$} & \multirow[t]{2}{*}{ Fetal biometry } & \multirow[t]{2}{*}{$\begin{array}{l}\text { Correlation } \\
\text { coefficient }\end{array}$} & \multirow[t]{2}{*}{ p value } & \multirow[t]{2}{*}{ Covariates } \\
\hline & & Parameter & Device & & & & & \\
\hline \multirow[t]{3}{*}{$\begin{array}{l}\text { Ikenoue et al. } \\
\text { (23) }\end{array}$} & 109 & $\% \mathrm{BF}$ & DXA & 20,30 weeks & $\begin{array}{l}\text { Arm percent fat } \\
\text { area (30 weeks) }\end{array}$ & 0.45 & $p<0.001$ & $\begin{array}{l}\text { GA, Parity, BMI, GWG, SES, } \\
\text { Ethnicity, Obstetrical complications }\end{array}$ \\
\hline & & & & & $\begin{array}{l}\text { Thigh percent fat } \\
\text { area (30 weeks) }\end{array}$ & 0.26 & $p<0.05$ & \\
\hline & & & & & FAST (30 weeks) & 0.21 & $p<0.05$ & \\
\hline \multirow{3}{*}{$\begin{array}{l}\text { O'Connor } \\
\text { et al. (24) }\end{array}$} & 62 & Fat mass & ADP & $28,33,38$ weeks & FAST (38 weeks) & - & $\mathrm{p}<0.001$ & smoking \\
\hline & & & & & $\begin{array}{l}\text { Thigh fat thickness } \\
\text { (38weeks) }\end{array}$ & - & $p=0.004$ & \\
\hline & & & & & $\begin{array}{l}\text { Thigh fat thickness } \\
\text { (28weeks) }\end{array}$ & - & $p=0.023$ & \\
\hline \multirow{2}{*}{$\begin{array}{l}\text { Buhling et al. } \\
\text { (25) }\end{array}$} & 172 & Skinfold & Anthropometry* & 37 - weeks & FAST & 0.58 & $\mathrm{p}<0.001$ & BMI, placental site, amniotic fluid \\
\hline & & thickness & & & Thigh fat thickness & 0.64 & $\mathrm{p}<0.001$ & volume \\
\hline $\begin{array}{l}\text { Knight et al. } \\
\text { (26) }\end{array}$ & 106 & $\% \mathrm{BF}$ & ADP & 36-40 weeks & Arm fat area & - & $p<0.001$ & - \\
\hline \multirow[t]{4}{*}{ Lee et al. (27) } & 87 & $\% B F$ & ADP & 38 weeks (mean) & $\begin{array}{l}\text { Fractional thigh } \\
\text { volume }\end{array}$ & 0.68 & $p<0.001$ & $\begin{array}{l}\text { Age, parity, GA, sex, ethnicity, } \\
\text { Obstetrical complications }\end{array}$ \\
\hline & & & & & $\begin{array}{l}\text { Fractional arm } \\
\text { volume }\end{array}$ & 0.62 & - & \\
\hline & & & & & $\begin{array}{l}\text { Estimated fetal } \\
\text { weight }\end{array}$ & 0.55 & - & \\
\hline & & & & & $\begin{array}{l}\text { Abdominal } \\
\text { circumference }\end{array}$ & 0.50 & - & \\
\hline \multirow[t]{2}{*}{$\begin{array}{l}\text { Moyer-Mileur } \\
\text { et al. ( } 21)\end{array}$} & 47 & $\% B F$ & ADP & 35 week & $\begin{array}{l}\text { Estimated fetal } \\
\text { weight }\end{array}$ & 0.33 & $p<0.05$ & Parity, BMI, GWG, SES \\
\hline & & & & & $\begin{array}{l}\text { Abdominal } \\
\text { circumference }\end{array}$ & 0.37 & $p<0.05$ & \\
\hline \multirow{2}{*}{$\begin{array}{l}\text { Bernstein } \\
\text { et al. (28) }\end{array}$} & 36 & $\% \mathrm{BF}$ & Anthropometry* & 19-40 weeks & Thigh fat area & 0.63 & $p<0.001$ & Age, Parity, BMI, GA, GWG, sex \\
\hline & & & & & Arm fat area & 0.45 & $\mathrm{p}<0.05$ & \\
\hline
\end{tabular}

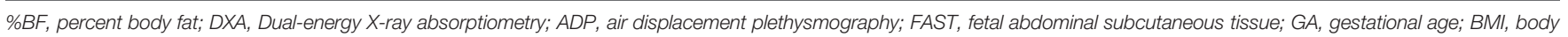
mass index; GWG, gestational weight gain, SES, socioeconomical status.

*Sum of subcutaneous skinfold thickness.

introduced by Lee et al., defined as the cylindrical limb subvolume based on the central $50 \%$ of the total humeral or femoral length (40). It is a reproducible measure for quantifying fetal soft tissue volume, including fat mass and lean mass (41, 42). Usually, before starting fractional limb volume measures, sonographers are required to measure 20-30 training data sets. The learning curve for technically satisfactory measurements of fractional limb volume is quickly achieved without difficulty (43). Recently, automated fractional limb volume measures has also been investigated (44). Fractional limb volume is useful to improve birth weight estimation (43) and accounts for a greater proportion of variation in neonatal body fat percentage than conventional fetal measures such as estimated fetal weight (27). The growth trajectory of fetal soft tissue volume (especially fat mass) accelerates early in the third trimester $(45,46)$, which coincides with the accelerated growth of fractional limb volume around 30 weeks of gestation $(44,47,48)$. We recently reported greater fetal fractional arm volume among mothers with gestational diabetes in late gestation (49).

\section{Maternal-Fetal Factors That Affect Fetal Body Composition}

Maternal pregravid body mass index (BMI) and diabetes are well known determinants of fetal growth, in particular fetal adiposity
$(50,51)$. Infants born to women with higher BMI have increased percentage body fat as compared to infants born to women with normal BMI $(52,53)$. Overweight or obese women with normal glucose tolerance levels still have infants with increased adiposity (50). Maternal gestational weight gain and presence of gestational diabetes have been associated with increased fetal abdominal subcutaneous fat thickness (54). Moreover, several biomarkers (maternal systemic interleukin-6, cord blood leptin and insulin-like growth factor) potentially affect fetal body composition $(55,56)$.

\section{Fetal Liver Blood Flow Volume and Infant Body Composition}

Fetal liver blood flow volume has recently emerged as one of the determinants of fetal growth and subsequent infant body composition $(57,58)$. The fetal liver is the primary site where nutrient interconversion and de novo synthesis occur (59). Hence, variation in the relative distribution of umbilical venous blood flow shunting either through the ductus venosus or through the fetal liver has been proposed as a mechanism of fetal adaptation to intrauterine conditions $(23,60,61)$.

Several studies have been conducted investigating the association between fetal liver blood flow volume and maternal pregravid BMI (62), gestational weight gain (63), serum glucose 
level (64-66), and fetal growth restriction (67). More recent report showed the correlation between fetal liver blood flow volume and placental corticotrophin releasing hormone, which is a paracrine determinant of the placental vasculature (68). Considering these previous reports, assessing fetal liver blood flow volume may help better understand the mechanisms influencing fetal growth and body composition.

\section{FUTURE PERSPECTIVES}

Further studies are warranted to determine the association between ultrasound-based measures of fetal body composition and metabolic dysfunction in later life. It is also important to investigate the factors (maternal demographic background, metabolic status including dyslipidemia and dysglycemia, and placental transporters of the nutrients) that affect fetal body composition and fat deposition (69).

Fetal fat mass and fractional limb volume could also be surrogate markers of fetal nutritional status, to distinguish constitutionally small/large fetus from malnourished/ overnourished fetus. Physiological diversity and heterogeneity in fetal growth velocity patterns (especially in the third trimester of gestation) has been reported (70). Additionally. the growth trajectory of fetal soft tissue volume (especially fat mass) accelerates early in the third trimester $(45,46)$. Based on these, sequential measures of fetal fat mass and fractional limb volume in the third trimester (e.g. every 2-4 weeks) could be clinically useful to distinguish constitutionally small/large fetus from malnourished/overnourished fetus. These can help better understand the "thrifty" or "drifty" phenotype of the fetus, both of which are predisposed to the metabolic syndrome in

\section{REFERENCES}

1. Barker DJ, Winter PD, Osmond C, Margetts B, Simmonds SJ. Weight in Infancy and Death From Ischaemic Heart Disease. Lancet (1989) 2 (8663):577-80. doi: 10.1016/S0140-6736(89)90710-1

2. Roseboom T, de Rooij S, Painter R. The Dutch Famine and Its Long-Term Consequences for Adult Health. Early Hum Dev (2006) 82(8):485-91. doi: 10.1016/j.earlhumdev.2006.07.001

3. Hapo Study Cooperative Research Group. Hyperglycemia and Adverse Pregnancy Outcome (HAPO) Study: Associations With Neonatal Anthropometrics. Diabetes (2009) 58(2):453-9. doi: 10.2337/db08-1112

4. Boney CM, Verma A, Tucker R, Vohr BR. Metabolic Syndrome in Childhood: Association With Birth Weight, Maternal Obesity, and Gestational Diabetes Mellitus. Pediatrics (2005) 115(3):e290-6. doi: 10.1542/peds.2004-1808

5. Oken E, Gillman MW. Fetal Origins of Obesity. Obes Res (2003) 11(4):496506. doi: 10.1038/oby.2003.69

6. Entringer S, Buss C, Swanson JM, Cooper DM, Wing DA, Waffarn F, et al. Fetal Programming of Body Composition, Obesity, and Metabolic Function: The Role of Intrauterine Stress and Stress Biology. J Nutr Metab (2012) 632548. doi: 10.1155/2012/632548

7. Gluckman PD, Hanson MA. Living With the Past: Evolution, Development, and Patterns of Disease. Science (New York N Y) (2004) 305(5691):1733-6. doi: 10.1126/science.1095292

8. Schmelzle HR, Quang DN, Fusch G, Fusch C. Birth Weight Categorization According to Gestational Age Does Not Reflect Percentage Body Fat in Term and Preterm Newborns. Eur J Pediatr (2007) 166(2):161-7. doi: 10.1007/s00431-006-0209-X later life. Further studies should be conducted to evaluate how these findings translate into clinical interventions for altered fetal growth and body composition. This could potentially lead to the primary prevention of future risk of metabolic dysfunction.

\section{CONCLUSION}

An ultrasound-based measure of fetal fat mass has been established that provides new insights into the evaluation of fetal growth and body composition, and its relationship with newborn adiposity. The ability to detect extreme variations in fetal fat deposition may help understand alterations in fetal body composition in pathophysiological conditions, such as fetal growth restriction or fetal macrosomia. Further studies are warranted to elucidate the maternal or placental factors that affect fetal fat deposition and newborn body composition. Elucidating these factors could help develop clinical intervention strategies for altered fetal growth and body composition, which potentially lead to primary prevention of the metabolic dysfunction in later life.

\section{AUTHOR CONTRIBUTIONS}

SI researched data, wrote the manuscript. SI, YK, TE, MT, and DO contributed to discussion and reviewed the manuscript. All authors contributed to the article and approved the submitted version.

\section{FUNDING}

This work was funded by the Japan Society for the Promotion of Science, KAKENHI Grant Number 20K18231.
9. Shaw M, Lutz T, Gordon A. Does Low Body Fat Percentage in Neonates Greater Than the 5th Percentile Birthweight Increase the Risk of Hypoglycaemia and Neonatal Morbidity? J Paediatr Child Health (2019) 55 (12):1424-8. doi: 10.1111/jpc.14433

10. Kuriyan R, Naqvi S, Bhat KG, Ghosh S, Rao S, Preston T, et al. The Thin But Fat Phenotype Is Uncommon at Birth in Indian Babies. J Nutr (2020) 150 (4):826-32. doi: 10.1093/jn/nxz305

11. Catalano PM, Farrell K, Thomas A, Huston-Presley L, Mencin P, de Mouzon SH, et al. Perinatal Risk Factors for Childhood Obesity and Metabolic Dysregulation. Am J Clin Nutr (2009) 90(5):1303-13. doi: 10.3945/ajcn.2008.27416

12. Lowe WLJr., Scholtens DM, Kuang A, Linder B, Lawrence JM, Lebenthal Y, et al. Hyperglycemia and Adverse Pregnancy Outcome Follow-Up Study (HAPO FUS): Maternal Gestational Diabetes Mellitus and Childhood Glucose Metabolism. Diabetes Care (2019) 42(3):372-80. doi: 10.2337/dc18-1646

13. Kuzawa CW, Chugani HT, Grossman LI, Lipovich L, Muzik O, Hof PR, et al. Metabolic Costs and Evolutionary Implications of Human Brain Development. Proc Natl Acad Sci USA (2014) 111(36):13010-5. doi: 10.1073/pnas.1323099111

14. Bougneres PF, Lemmel C, Ferre P, Bier DM. Ketone Body Transport in the Human Neonate and Infant. J Clin Invest (1986) 77(1):42-8. doi: 10.1172/ JCI112299

15. Chen LW, Tint MT, Fortier MV, Aris IM, Shek LP, Tan KH, et al. Which Anthropometric Measures Best Reflect Neonatal Adiposity? Int J Obes (2018) 42(3):501-6. doi: 10.1038/ijo.2017.250

16. Catalano PM, Tyzbir ED, Allen SR, McBean JH, McAuliffe TL. Evaluation of Fetal Growth by Estimation of Neonatal Body Composition. Obstet Gynecol (1992) 79(1):46-50 
17. de Knegt VE, Carlsen EM, Bech Jensen JE, Lade Rasmussen AM, Pryds O. DXA Performance in a Pediatric Population: Precision of Body Composition Measurements in Healthy Term-Born Infants Using Dual-Energy X-Ray Absorptiometry. J Clin Densitom (2015) 18(1):117-23. doi: 10.1016/ j.jocd.2014.08.004

18. Moraitis AA, Shreeve N, Sovio U, Brocklehurst P, Heazell AEP, Thornton JG, et al. Universal Third-Trimester Ultrasonic Screening Using Fetal Macrosomia in the Prediction of Adverse Perinatal Outcome: A Systematic Review and Meta-Analysis of Diagnostic Test Accuracy. PloS Med (2020) 17 (10):e1003190. doi: 10.1371/journal.pmed.1003190

19. Law TL, Korte JE, Katikaneni LD, Wagner CL, Ebeling MD, Newman RB. Ultrasound Assessment of Intrauterine Growth Restriction: Relationship to Neonatal Body Composition. Am J Obstet Gynecol (2011) 205(3):255.e1-6. doi: 10.1016/j.ajog.2011.06.027

20. Coomarasamy A, Connock M, Thornton J, Khan KS. Accuracy of Ultrasound Biometry in the Prediction of Macrosomia: A Systematic Quantitative Review. BJOG (2005) 112(11):1461-6. doi: 10.1111/j.1471-0528.2005.00702.x

21. Moyer-Mileur LJ, Slater H, Thomson JA, Mihalopoulos N, Byrne J, Varner MW. Newborn Adiposity Measured by Plethysmography Is Not Predicted by Late Gestation Two-Dimensional Ultrasound Measures of Fetal Growth. J Nutr (2009) 139(9):1772-8. doi: 10.3945/jn.109.109058

22. Schwartz J, Galan H. Ultrasound in Assessment of Fetal Growth Disorders: Is There a Role for Subcutaneous Measurements? Ultrasound Obstet Gynecol (2003) 22(4):329-35. doi: 10.1002/uog.887

23. Ikenoue S, Waffarn F, Ohashi M, Sumiyoshi K, Ikenoue C, Buss C, et al. Prospective Association of Fetal Liver Blood Flow at 30 Weeks Gestation With Newborn Adiposity. Am J Obstet Gynecol (2017) 217(2):204.e1-8. doi: 10.1016/j.ajog.2017.04.022

24. O'Connor C, Doolan A, O'Higgins A, Segurado R, Sheridan-Pereiraet M, Turner MJ, et al. Fetal Subcutaneous Tissue Measurements in Pregnancy as a Predictor of Neonatal Total Body Composition. Prenat Diagn (2014) 34:1-4. doi: 10.1002/pd.4400

25. Buhling KJ, Doll I, Siebert G, Catalano PM. Relationship Between Sonographically Estimated Fetal Subcutaneous Adipose Tissue Measurements and Neonatal Skinfold Measurements. Ultrasound Obstet Gynecol (2012) 39(5):558-62. doi: 10.1002/uog.10092

26. Knight CL, Rueda S, Noble JA, Papageorghiou AT. Fetal Arm Fat: An In Utero Marker of Body Composition? Ultrasound Obstet Gynecol (2012) 40 (S1):106.

27. Lee W, Balasubramaniam M, Deter RL, Hassan SS, Gotsch F, Kusanovic JP, et al. Fetal Growth Parameters and Birth Weight: Their Relationship to Neonatal Body Composition. Ultrasound Obstet Gynecol (2009) 33(4):4416. doi: 10.1002/uog. 6317

28. Bernstein IM, Goran MI, Amini SB, Catalano PM. Differential Growth of Fetal Tissues During the Second Half of Pregnancy. Am J Obstet Gynecol (1997) 176 (1):28-32. doi: 10.1016/S0002-9378(97)80006-3

29. Poissonnet CM, Burdi AR, Garn SM. The Chronology of Adipose Tissue Appearance and Distribution in the Human Fetus. Early Hum Dev (1984) 10 (1-2):1-11. doi: 10.1016/0378-3782(84)90106-3

30. Sparks JW. Human Intrauterine Growth and Nutrient Accretion. Semin Perinatol (1984) 8(2):74-93.

31. Fields DA, Teague AM, Short KR, Chernausek SD. Evaluation of DXA vs. MRI for Body Composition Measures in 1-Month Olds. Pediatr Obes (2015) 10(5):e8-10. doi: 10.1111/ijpo.12021

32. Ikenoue S, Waffarn F, Sumiyoshi K, Ohashi M, Ikenoue C, Buss C, et al. Association of Ultrasound-Based Measures of Fetal Body Composition With Newborn Adiposity. Pediatr Obes (2017) 12 Suppl 1:86-93. doi: 10.1111/ ijpo.12198

33. Jeanty P, Romero R, Hobbins JC. Fetal Limb Volume: A New Parameter to Assess Fetal Growth and Nutrition. J Ultrasound Med (1985) 4(6):273-82. doi: 10.7863/jum.1985.4.6.273

34. Gardeil F, Greene R, Stuart B, Turner MJ. Subcutaneous Fat in the Fetal Abdomen as a Predictor of Growth Restriction. Obstet Gynecol (1999) 94 (2):209-12. doi: 10.1097/00006250-199908000-00010

35. Petrikovsky BM, Oleschuk C, Lesser M, Gelertner N, Gross B. Prediction of Fetal Macrosomia Using Sonographically Measured Abdominal Subcutaneous Tissue Thickness. J Clin Ultrasound (1997) 25(7):378-82. doi: 10.1002/(sici) 1097-0096(199709)25:7<378::aid-jcu5>3.0.co;2-7
36. Abramowicz JS, Rana S, Abramowicz S. Fetal Cheek-to-Cheek Diameter in the Prediction of Mode of Delivery. Am J Obstet Gynecol (2005) 192(4):1205-11; discussion 11-3. doi: 10.1016/j.ajog.2005.01.008

37. Matsumoto M, Yanagihara T, Hata T. Three-Dimensional Qualitative Sonographic Evaluation of Fetal Soft Tissue. Hum Reprod (2000) 15 (11):2438-42. doi: 10.1093/humrep/15.11.2438

38. Abramowicz JS, Sherer DM, Woods JRJr. Ultrasonographic Measurement of Cheek-to-Cheek Diameter in Fetal Growth Disturbances. Am J Obstet Gynecol (1993) 169(2 Pt 1):405-8. doi: 10.1016/0002-9378(93)90097-3

39. Abramowicz JS, Robischon K, Cox C. Incorporating Sonographic Cheek-toCheek Diameter, Biparietal Diameter and Abdominal Circumference Improves Weight Estimation in the Macrosomic Fetus. Ultrasound Obstet Gynecol (1997) 9(6):409-13. doi: 10.1046/j.1469-0705.1997.09060409.x

40. Lee W, Deter RL, Ebersole JD, Huang R, Blanckaert K, Romero R. Birth Weight Prediction by Three-Dimensional Ultrasonography: Fractional Limb Volume. J Ultrasound Med (2001) 20(12):1283-92. doi: 10.7863/ jum.2001.20.12.1283

41. Lee W. A Commentary About the Importance of Fetal and Neonatal SoftTissue Assessment. BJOG (2018) 125(12):1567. doi: 10.1111/1471-0528.15303

42. Roelants JA, Vermeulen MJ, Koning IV, Groenenberg IAL, Willemsen SP, Hokken-Koelega ACS, et al. Foetal Fractional Thigh Volume: An Early 3D Ultrasound Marker of Neonatal Adiposity. Pediatr Obes (2017) 12 Suppl 1:6571. doi: 10.1111/ijpo.12231

43. Lee W, Mack LM, Sangi-Haghpeykar H, Gandhi R, Wu Q, Kang L, et al. Fetal Weight Estimation Using Automated Fractional Limb Volume With 2Dimensional Size Parameters: A Multicenter Study. J Ultrasound Med (2020) 39(7):1317-24. doi: 10.1002/jum.15224

44. Mack LM, Kim SY, Lee S, Sangi-Haghpeykar H, Lee W. Automated Fractional Limb Volume Measurements Improve the Precision of Birth Weight Predictions in Late Third-Trimester Fetuses. J Ultrasound Med (2017) 36 (8):1649-55. doi: 10.7863/ultra.16.08087

45. Pereira GR. Nutritional Assessment. In: RA Polin, WW Fox, SH Abman, editors. Fetal and Neonatal Physiology. Philadelphia: Elsevier/Saunders (2011). p. 341-51.

46. Ikenoue S, Akiba Y, Endo T, Kasuga Y, Yakubo K, Ishii R, et al. Defining the Normal Growth Curve of Fetal Fractional Limb Volume in a Japanese Population. J Clin Med (2021) 10(3):485. doi: 10.3390/jcm10030485

47. Sharma KA, Das D, Dadhwal V, Deka D, Singhal S, Vanamail P. TwoDimensional Fetal Biometry Versus Three-Dimensional Fractional Thigh Volume for Ultrasonographic Prediction Of Birthweight. Int J Gynecol Obstet (2019) 145(1):47-53. doi: 10.1002/ijgo.12770

48. Lee W, Balasubramaniam M, Deter RL, Hassan SS, Gotsch F, Kusanovic JP, et al. Fractional Limb Volume - A Soft Tissue Parameter of Fetal Body Composition: Validation, Technical Considerations and Normal Ranges During Pregnancy. Ultrasound Obstet Gynecol (2009) 33(4):427-40. doi: 10.1002/uog.6319

49. Akiba Y, Ikenoue S, Endo T, Kasuga Y, Ochiai D, Miyakoshi K, et al. Differences in Fetal Fractional Limb Volume Changes in Normal and Gestational Diabetic Pregnancies: An Exploratory Observational Study. BJOG (2021) 128(2):329-35. doi: 10.1111/1471-0528.16265

50. Sewell MF, Huston-Presley L, Super DM, Catalano P. Increased Neonatal Fat Mass, Not Lean Body Mass, Is Associated With Maternal Obesity. Am J Obstet Gynecol (2006) 195(4):1100-3. doi: 10.1016/j.ajog.2006.06.014

51. Catalano PM, Thomas A, Huston-Presley L, Amini SB. Increased Fetal Adiposity: A Very Sensitive Marker of Abnormal In Utero Development. Am J Obstet Gynecol (2003) 189(6):1698-704. doi: 10.1016/s0002-9378(03) 00828-7

52. Bennett AE, Kearney JM. Maternal Sociodemographic and Health Behaviours Associated With Adiposity in Infants as Measured by Air Displacement Plethysmography. Early Hum Dev (2019) 140:104887. doi: 10.1016/ j.earlhumdev.2019.104887

53. Breij LM, Steegers-Theunissen RP, Briceno D, Hokken-Koelega AC. Maternal and Fetal Determinants of Neonatal Body Composition. Horm Res Paediatr (2015) 84(6):388-95. doi: 10.1159/000441298

54. Rohl J, Huston-Presley L, Amini S, Stepanchak B, Catalano P. Factors Associated With Fetal Growth and Body Composition as Measured by Ultrasound. Am J Obstet Gynecol (2001) 185(6):1416-20. doi: 10.1067/ mob.2001.118846 
55. Radaelli T, Uvena-Celebrezze J, Minium J, Huston-Presley L, Catalano P, Hauguel-de Mouzon S. Maternal Interleukin-6: Marker of Fetal Growth and Adiposity. J Soc Gynecol Invest (2006) 13(1):53-7. doi: 10.1016/ j.jsgi.2005.10.003

56. Christou H, Connors JM, Ziotopoulou M, Hatzidakis V, Papathanassoglou E, Ringer SA, et al. Cord Blood Leptin and Insulin-Like Growth Factor Levels Are Independent Predictors of Fetal Growth. J Clin Endocrinol Metab (2001) 86(2):935-8. doi: 10.1210/jcem.86.2.7217

57. Tchirikov M, Kertschanska S, Sturenberg HJ, Schroder HJ. Liver Blood Perfusion as a Possible Instrument for Fetal Growth Regulation. Placenta (2002) 23 Suppl A:S153-8. doi: 10.1053/plac.2002.0810

58. Kessler J, Rasmussen S, Godfrey K, Hanson M, Kiserud T. Venous Liver Blood Flow and Regulation of Human Fetal Growth: Evidence From Macrosomic Fetuses. Am J Obstet Gynecol (2011) 204(5):429.e1-7. doi: 10.1016/j.ajog. 2010.12.038

59. Seifter S, Englard S. Energy Metabolism. In: IM Arias, editor. The Liver: Biology and Pathobiology. New York: Raven Press (1994). p. 323-64.

60. Godfrey KM, Haugen G, Kiserud T, Inskip HM, Cooper C, Harvey NC, et al. Fetal Liver Blood Flow Distribution: Role in Human Developmental Strategy to Prioritize Fat Deposition Versus Brain Development. PloS One (2012) 7(8): e41759. doi: 10.1371/journal.pone.0041759

61. Kuzawa CW. Fetal Origins of Developmental Plasticity: Are Fetal Cues Reliable Predictors of Future Nutritional Environments? Am J Hum Biol (2005) 17(1):5-21. doi: 10.1002/ajhb.20091

62. Haugen G, Hanson M, Kiserud T, Crozier S, Inskip H, Godfrey KM. Fetal Liver-Sparing Cardiovascular Adaptations Linked to Mother's Slimness and Diet. Circ Res (2005) 96(1):12-4. doi: 10.1161/01.RES.0000152391.45273.A2

63. Kessler J, Rasmussen S, Godfrey K, Hanson M, Kiserud T. Longitudinal Study of Umbilical and Portal Venous Blood Flow to the Fetal Liver: Low Pregnancy Weight Gain Is Associated With Preferential Supply to the Fetal Left Liver Lobe. Pediatr Res (2008) 63(3):315-20. doi: 10.1203/PDR.0b013e318163alde

64. Opheim GL, Moe Holme A, Blomhoff Holm M, Melbye Michelsen T, Muneer Zahid S, Paasche Roland MC, et al. The Impact of Umbilical Vein Blood Flow and Glucose Concentration on Blood Flow Distribution to the Fetal Liver and
Systemic Organs in Healthy Pregnancies. FASEB J (2020) 34(9):12481-91. doi: 10.1096/fj.202000766R

65. Lund A, Ebbing C, Rasmussen S, Kiserud T, Kessler J. Maternal Diabetes Alters the Development of Ductus Venosus Shunting in the Fetus. Acta Obstet Gynecol Scand (2018) 97(8):1032-40. doi: 10.1111/aogs.13363

66. Haugen G, Bollerslev J, Henriksen T. Human Fetoplacental and Fetal Liver Blood Flow After Maternal Glucose Loading: A Cross-Sectional Observational Study. Acta Obstet Gynecol Scand (2014) 93(8):778-85. doi: 10.1111/ aogs.12419

67. Bellotti M, Pennati G, De Gasperi C, Bozzo M, Battaglia FC, Ferrazzi E. Simultaneous Measurements of Umbilical Venous, Fetal Hepatic, and Ductus Venosus Blood Flow in Growth-Restricted Human Fetuses. Am J Obstet Gynecol (2004) 190(5):1347-58. doi: 10.1016/j.ajog.2003.11.018

68. Ikenoue S, Waffarn F, Ohashi M, Tanaka M, Gillen DL, Buss C, et al. Placental Corticotrophin Releasing Hormone Is a Modulator of Fetal Liver Blood Perfusion. J Clin Endocrinol Metab (2021) 106(3):646-53. doi: 10.1210/ clinem/dgaa908

69. Delhaes F, Giza SA, Koreman T, Eastabrook G, McKenzie CA, Bedell S, et al. Altered Maternal and Placental Lipid Metabolism and Fetal Fat Development in Obesity: Current Knowledge and Advances in Non-Invasive Assessment. Placenta (2018) 69:118-24. doi: 10.1016/j.placenta.2018.05.011

70. Sato N, Miyasaka N. Heterogeneity in Fetal Growth Velocity. Sci Rep (2019) 9 (1):11304. doi: 10.1038/s41598-019-47839-5

Conflict of Interest: The authors declare that the research was conducted in the absence of any commercial or financial relationships that could be construed as a potential conflict of interest.

Copyright (c) 2021 Ikenoue, Kasuga, Endo, Tanaka and Ochiai. This is an open-access article distributed under the terms of the Creative Commons Attribution License (CC BY). The use, distribution or reproduction in other forums is permitted, provided the original author(s) and the copyright owner(s) are credited and that the original publication in this journal is cited, in accordance with accepted academic practice. No use, distribution or reproduction is permitted which does not comply with these terms. 